\title{
Генерация третьей гармоники в РДС кристаллах от волоконного ВКР лазера как подход для получения непрерывного синего излучения
}

\author{
А.А. Сурин ${ }^{1, *}$, А.А. Мольков ${ }^{1,2}$, Т.Е. Борисенко ${ }^{1}$, К.Ю. Прусаков ${ }^{1,2}$ \\ ${ }^{I}$ НТО «ИРЭ-Полюс» \\ ${ }^{2}$ Московский физико-технический институт (Государственный Университет) \\ "E-mail: asurin@ntoire-polus.ru
}

DOI:10.31868/RFL2018.90-91

Компактные и надежные синие лазерные источники большой мощности (более 1 Вт) востребованы для различных применений, таких как спектроскопия, голография, проецирование изображений и др. Для получения синего излучения с мощностью в несколько единиц ватт часто используют традиционный синхронизм в нелинейно-оптических кристаллах при внутрирезонаторной генерации второй гармоники (ГВГ) от твердотельного лазера [1,2]. Для упрощения оптической схемы можно применять однопроходную схему генерации гармоники в кристаллах с регулярной доменной структурой (РДС кристаллы). Однако, по литературным данным, максимальная выходная мощность таких лазерных источников ограничена значением 190 мВт [3].

В работе [4] был предложен простой метод для получения интенсивного непрерывного лазерного излучения на любой длине волны из спектрального диапазона 560 - 770 нм. Их метод основан на однопроходной ГВГ в РДС кристалле от излучения волоконного ВКР лазера. В работах $[5,6]$ этот подход был доработан и улучшен для получения бо́льших мощностей и эффективностей преобразования в диапазоне длин волн, упомянутом выше. В нашей работе мы расширили данный метод для получения лазерного излучения в синем спектральном диапазоне. Мы использовали схему однопроходной генерации третьей гармоники (ГТГ) от волоконного ВКР лазера с длиной волны излучения 1316 нм в РДС кристалле стехиометрического танталата лития для получения излучения с длиной волны 438 нм. Схема экспериментальной установки представлена на рисунке 1.

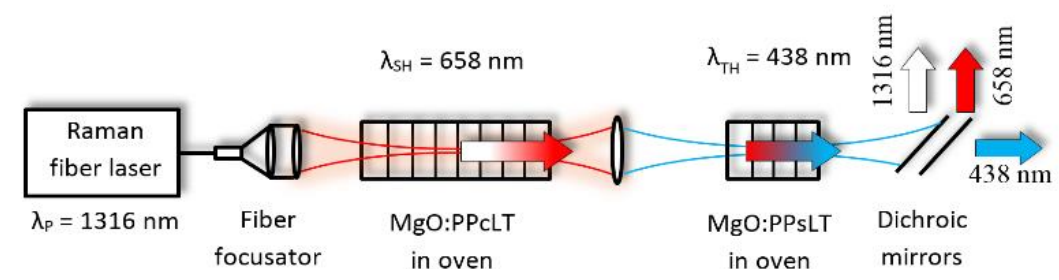

Рис. 1. Схема экспериментальной установки

Нами был разработан линейно-поляризованный волоконный ВКР лазер с длиной волны излучения 1316 нм с максимальной выходной мощностью 45 Вт и спектральной шириной линии 0.224 нм (FWHM).

Для генерации второй гармоники ИК излучение накачки было сфокусировано в РДС кристалл конгруентнтого танталата лития, помещенного в термостат, позволяющий контролировать температуру с точностью $0.1{ }^{\circ} \mathrm{C}$. Мы получили 8.1 Вт излучения с длиной волны 658 нм с эффективностью преобразования $18 \%$.

Затем излучение накачки на 1316 нм и второй гармоники фокусировалось в РДС кристалл стехиометрического танталата лития для генерации суммарной 
частоты. Кристалл также был помещен в термостат, аналогичный использованному для ГВГ. Для фильтрации синего излучения от излучения первой и второй гармоник было использовано два дихроичных зеркала. Мы получили на выходе более 1.2 Вт непрерывного одномодового линейнополяризованного лазерного излучения с длиной волны 438 нм с эффективностью преобразования от излучения накачки 1316 нм 3.3\%. Спектр излучения и кривые температурного синхронизма представлены на рисунке 2. Искажение формы кривых говорит о тепловых ограничивающих факторах в кристалле.
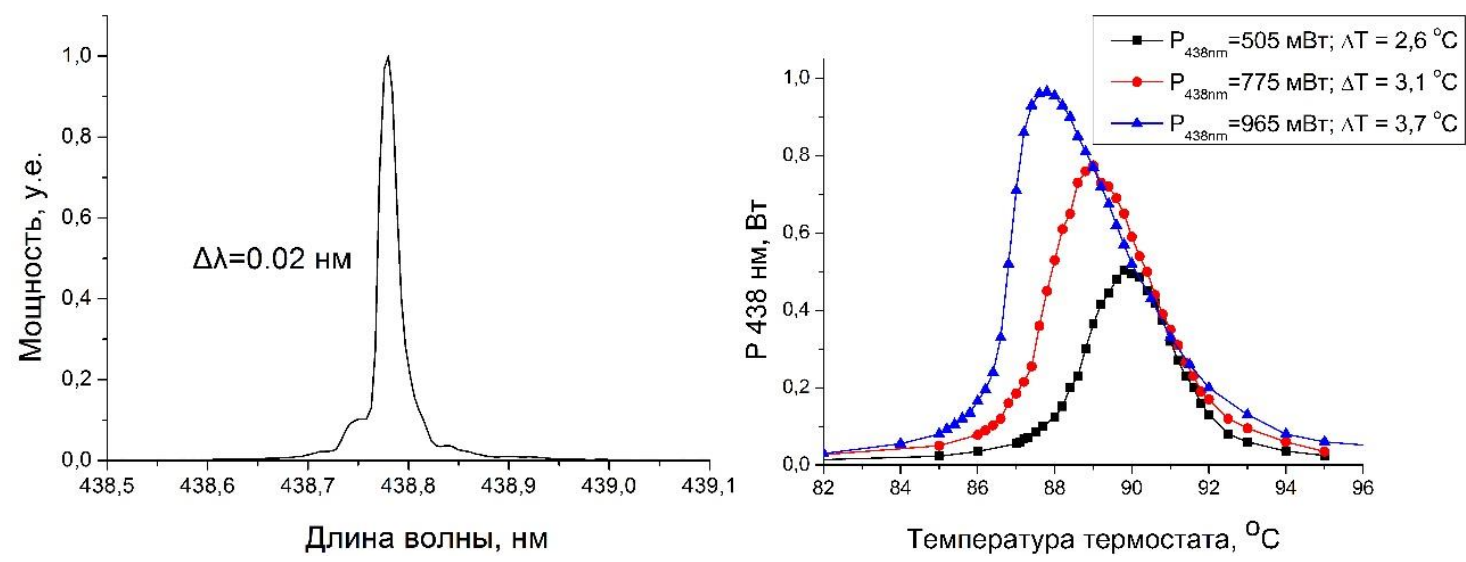

Рис. 2. Спектр излучения (слева) и кривые температурного синхронизма (справа)

Данные результаты, по нашим сведениям, является мировым рекордом по получению непрерывного лазерного излучения в синем спектральном диапазоне, в частности на длине волны 438 нм, путем генерации гармоник в РДС кристаллах.

Тем самым, в данной работе было продемонстрировано, что описанный в $[5,6]$ подход позволяет получать не только видимое лазерное излучение в диапазоне длин волн от 530 до 660 нм, но он также может быть расширен для получения одномодового излучения в ультрафиолетовом и синем диапазоне спектра.

\section{Литература}

[1] Z. Quan, Y. Yi, L. Bin, Q. Dapeng, and Z. Ling, J. Opt. Soc. Am. B 26, 1238-1242 (2009).

[2] Y. Kong, X. Lin, R. Li, Z. Xu, X. Han, Optics Express 14, 6543-6549 (2006).

[3] K. Mizuuchi, et al, Japanese Journal of Applied Physics 43, L1293 - L1295 (2004).

[4] D. Georgiev, et al, Optics Express 13, 6772-6776 (2005).

[5] A.A. Surin, et al, Quantum Electronics 46, 1097 - 1101 (2016).

[6] Surin A.A., Borisenko T.E. and Larin S.V., Optics Letters 41, 2644-2647 (2016). 